\title{
Does Dipyridamole Attenuate Whole Body $\gamma$-rays-Induced Oxidative Damage in Male Rats?
}

\author{
S. F. Salama* and N. M. El-Fatih
}

Radiation Biology Dept., National Centre for Radiation Research and Technology (NCRRT), P .O. Box; 29 Nasr City, Egypt. E. mail; Safwatfaried@hotmail.com

\footnotetext{
IPYRIDAMOLE (DP), a pyrimido-pyrimidinic derivative is a phosphodiesterase inhibitor, chemically related to adenosine and inhibits the cellular uptake of adenosine with antithrombotic and vasodilation actions. The aim of this study is to evaluate the effect of subcutaneous administration of DP (100 mg/ kg body wt, 5 times/ week for 3 weeks) on oxidative stress in 6 Gy $\gamma$-irradiated rats delivered at a single dose.

Irradiated group revealed significant increase of serum malondialdehyde (MDA), advanced protein oxidation products (AOPP), protein carbonyl (PCO), nitric oxide (NO), urea, triglycerides and cholesterol contents. While, there was a significant decrease of blood reduced glutathione (GSH), erythrocytes (RBCs) and platelets counts, haemoglobin content $(\mathrm{Hb})$, haemotocrit value (Hct), count of total leukocytes, neutrophils and lymphocytes.

Irradiated DP treated rats showed significant improvement in the radiation-induced disorders in all tested parameters. The current study highlights DP as promising agent which could strengthen the defence mechanisms of the physiological systems against the oxidative stress induced by ionising irradiation.

Keywords: dipyridamole, $\gamma$-rays, oxidative damage, rats.
}

The absorption of ionising radiation by living cells can directly disrupt atomic structures, producing chemical and biological changes. It can also act indirectly through radiolysis of water, thereby generating reactive chemical species that may damage nucleic acids, proteins and lipids (Hall and Giaccia, 2006). Together, the direct and indirect effects of radiation initiate a series of biochemical and molecular signalling events that may repair the damage or culminate in permanent physiological changes or cell death. Oxidative changes, including protein carbonisation, lipid peroxidation, and enhanced rates of 
spontaneous gene mutations and neoplastic transformation (Buonanno et al., 2011) responsible for most of the effects of ionizing radiation in mammalian cells, occur during or shortly after the radiation exposure which continue to arise for days and months after the initial exposure (Petkau, 1987). Since the beginning of the nuclear era, despite extensive research on the development of radio protectors from natural and synthetic compounds, success has been limited. Therefore, attempts have been made to improve the therapeutic effect of radiotherapy by minimizing normal tissue damage to acceptable level by using synthetic compounds.

DP, a pyrimido-pyrimidinic derivative, chemically related to adenosine, inhibits the cellular uptake of adenosine with antithrombotic and vasodilation actions (Di Salvo et al., 1996) and is effective in the secondary prevention of cerebrovascular disease (Diener et al., 1996). It has been suggested to inhibit platelet phosphodiesterase and stimulate the release of prostacyclin (Constantini et al., 1990). Pospisil et al. (1993) reported that the elevation of extracellular adenosine induced radio protective action in mouse caused by the effect of the treatment on the cardiovascular system and enhanced regeneration of haematopoietic stem cells. At clinically relevant concentrations, DP protects erythrocyte membranes from oxidation and spares the antioxidant power of erythrocytes (Kusmic et al., 2000). Furthermore, DP suppresses oxygen free radical formation in platelets and endothelial cells and improves cellular redox status (Chakrabarti et al., 2005). This work establishes the ability of DP to attenuate the oxidative damage induced by a single dose of 6 Gy $\gamma$-rays.

\section{Material and Methods}

\section{Animals}

Forty eight mature male Swiss albino rats weighing from 130 to $150 \mathrm{~g}$, were obtained from the Nuclear Research Centre, Inchas, Egypt. The animals were maintained on a commercial standard pellet diet and tap water ad libitum.

\section{Irradiation and DP treatment}

Whole body $\gamma$-irradiation was performed using a Canadian ${ }^{137} \mathrm{Cs}$ Gamma Cell-40 at NCRRT, Egypt; at a dose rate $0.43 \mathrm{~Gy} / \mathrm{min}$. Rats were exposed to 6 Gy applied as a shot dose to induce drastic radiobiological changes.

Egypt. J. Rad. Sci. Applic., Vol. 24, No. 2 (2011) 
DP (Sigma, St. Louis, MO, USA) was dissolved in $0.4 \%$ tartaric acid and injected subcutaneously (s.c.) at a dose of $100 \mathrm{mg} / \mathrm{Kg} 5$ times/ week (Ueda et al., 1996), as the mean peritoneal half-life for total extractable DP was $3.3 \pm 1.9 \mathrm{~h}$ (Chan et al., 1988).

Animals were divided into 1- Untreated control group. 2- Animals s.c. treated with $0.4 \%$ tartaric acid ( 5 times/ week for 3 weeks). 3 - Animals were s.c. treated ( 5 times/ week for 3 weeks) with DP $(100 \mathrm{mg} / \mathrm{kg})$. 4- Animals irradiated at a dose of 6 Gy $\gamma$-rays. 5- Animals irradiated at a dose of 6 Gy $\gamma$-rays and $2 \mathrm{~h}$ post irradiation, were s.c. treated ( 5 times/ week for 3 weeks) with that $0.4 \%$ tartaric acid. 6- Irradiated rats at a dose of $6 \mathrm{~Gy}$, that were s.c. administered 5 times/ week for 3 weeks with DP $(100 \mathrm{mg} / \mathrm{kg})$. Animals were scarified according to the ethical considerations of animal rights at the end of experiment (22 days).

\section{Collection of blood and tissue samples}

At the end of experiment, animals were anesthetized with ether. Two blood samples were immediately collected by heart puncture. The first sample was collected in heparinised tube for haematological assays. The second blood sample was centrifuged (1000 xg for $10 \mathrm{~min}$ ), collected in test tubes with screw caps and serum was stored at $-20^{\circ} \mathrm{C}$ until analyzed.

\section{Haematological and biochemical assays}

The first heparinised blood sample was used for RBCs and platelet counts, $\mathrm{Hb}$, Hct, total leukocyte and absolute neutrophil and lymphocyte counts were analysed by automated blood counter (coulter model T $450 \mathrm{x}$, Contronics Co., USA). Blood GSH content was measured according to Beutler et al. (1963). Serum MDA was estimated according to Yoshioka et al. (1979). AOPP was measured according to Witko-Sarsat et al. (1998). Protein-carbonyl value was determined according to Reznick and Packer (1994), using Sigma-Alderch chemical Co. (St Louis, USA). NO level was measured using Griess reagent, Calbiochem kit, according to Green et al. (1982). Serum cholesterol and triglycerides were measured using kits of Spinreact Company, Spain, according to Richmound (1973) and Fossati and Prencipe (1982), respectively. Serum total proteins and urea were determined by kits according to the methods of Lowry et al. (1951) and Tobacco et al. (1979), respectively.

Egypt. J. Rad. Sci. Applic., Vol. 24, No. 2 (2011) 


\section{Statistical analysis}

Data was expressed as means \pm S.E. Comparisons among groups $(\mathrm{n}=8)$ were performed by one-way analysis of variance (ANOVA) followed by Duncans post-test. Differences were considered statistically significant at $P<0.05$ (Zar, 1999).

\section{Results}

Duncans multiple range test revealed non significant differences between control groups as well as tartaric acid and DP treated groups for all estimated parameters except for triglycerides and cholesterol contents in DP group, which showed significant decrease as compared with control group.

TABLE 1. Serum NO, AOPP, PCO and urea in different animal groups.

\begin{tabular}{|l|c|c|c|c|}
\hline \multicolumn{1}{|c|}{ Groups } & $\begin{array}{c}\text { NO } \\
\mu \mathrm{mol} / \mathrm{l}\end{array}$ & $\begin{array}{c}\text { AOPP } \\
\mu \mathrm{mol} / 1\end{array}$ & $\begin{array}{c}\text { PCO } \\
\mathrm{nmol} / \mathrm{mg} \text { protein }\end{array}$ & $\begin{array}{c}\text { Urea } \\
\mathrm{mg} / \mathrm{dl}\end{array}$ \\
\hline Control & $78.83 \pm 3.0^{\mathrm{b}}$ & $49.18 \pm 3.35^{\mathrm{b}}$ & $0.66 \pm 0.07$ & $54.02 \pm 6.01^{\mathrm{b}}$ \\
\hline Tartaric acid & $77.6 \pm 2.95^{\mathrm{b}}$ & $47.28 \pm 4.1^{\mathrm{b}}$ & $0.67 \pm 0.06$ & $55.02 \pm 7.0^{\mathrm{b}}$ \\
\hline DP $(100 \mathrm{mg} / \mathrm{kg})$ & $81.17 \pm 4.4^{\mathrm{b}}$ & $38.75 \pm 3.9^{\mathrm{b}}$ & $0.61 \pm 0.04$ & $46.02 \pm 5.01^{\mathrm{b}}$ \\
\hline Irrad $(6 \mathrm{~Gy})$ & $97.5 \pm 2.19^{\mathrm{a}}$ & $63.84 \pm 5.27^{\mathrm{a}}$ & $1.42 \pm 0.12^{\mathrm{a}}$ & $67.02 \pm 7.01^{\mathrm{a}}$ \\
\hline $\begin{array}{l}\text { Irrad+ } \\
\text { Tartaric acid }\end{array}$ & $96.33 \pm 3.17^{\mathrm{a}}$ & $62.52 \pm 3.7^{\mathrm{a}}$ & $1.44 \pm 0.13^{\mathrm{a}}$ & $66.02 \pm 5.9^{\mathrm{a}}$ \\
\hline Irrad+ DP & $85.0 \pm 1.97^{\mathrm{b}}$ & $48.199 \pm 3.6^{\mathrm{b}}$ & $0.99 \pm 0.05^{\mathrm{b}}$ & $57.5 \pm 6.3^{\mathrm{b}}$ \\
\hline
\end{tabular}

a:significant with control. b:significant with irradiated group. Mean \pm S.E. significantly at $P<0.05$.

Serum AOPP, PCO, urea, NO values were increased significantly in animals exposed to 6 Gy $\gamma$-rays, compared to control group. While treatment with DP post irradiation has shown significant decreased in serum AOPP, PCO, $\mathrm{NO}$ and urea concentrations, compared to $\gamma$-irradiated group, Table 1.

TABLE 2. Blood GSH, serum lipid peroxidation, cholesterol and triglycerides in different animal groups.

\begin{tabular}{|l|c|c|c|c|}
\hline \multicolumn{1}{|c|}{ Groups } & $\begin{array}{c}\text { GSH } \\
\mathrm{mg} / \mathrm{dl}\end{array}$ & $\begin{array}{c}\text { MDA } \\
\mathrm{nmol} / \mathrm{L}\end{array}$ & $\begin{array}{c}\text { Cholesterol } \\
\mathrm{mg} / \mathrm{dl}\end{array}$ & $\begin{array}{c}\text { Triglycerides } \\
\mathrm{mg} / \mathrm{dl}\end{array}$ \\
\hline Control & $32.28 \pm 2.1^{\mathrm{b}}$ & $27.9 \pm 1.41^{\mathrm{b}}$ & $62.44 \pm 2.0^{\mathrm{b}}$ & $96.4 \pm 2.4^{\mathrm{b}}$ \\
\hline Tartaric acid & $33.26 \pm 3.34 \mathrm{~b}$ & $27.35 \pm 1.2^{\mathrm{b}}$ & $62.15 \pm 2.58^{\mathrm{b}}$ & $94.5 \pm 2.3^{\mathrm{b}}$ \\
\hline DP $(100 \mathrm{mg} / \mathrm{kg})$ & $33.31 \pm 3.7^{\mathrm{b}}$ & $29.75 \pm 2.5^{\mathrm{b}}$ & $41.73 \pm 3.0^{\mathrm{ab}}$ & $88.41 \pm 2.29^{\mathrm{ab}}$ \\
\hline Irrad $(6 \mathrm{~Gy})$ & $21.98 \pm 1.11^{\mathrm{a}}$ & $46.62 \pm 4.2^{\mathrm{a}}$ & $95.16 \pm 6.2^{\mathrm{a}}$ & $137.4 \pm 5.0^{\mathrm{a}}$ \\
\hline $\begin{array}{l}\text { Irrad+ } \\
\text { Tartaric acid }\end{array}$ & $23.83 \pm 1.2 \mathrm{a}$ & $40.34 \pm 3.15^{\mathrm{a}}$ & $94.57 \pm 4.9^{\mathrm{a}}$ & $134.0 \pm 4.9^{\mathrm{a}}$ \\
\hline Irrad+ DP & $29.78 \pm 2.1^{\mathrm{b}}$ & $29.74 \pm 2.34^{\mathrm{b}}$ & $82.16 \pm 3.5^{\mathrm{a}, \mathrm{b}}$ & $108.8 \pm 5.8^{\mathrm{b}}$ \\
\hline
\end{tabular}

Legends as in Table 1.

Egypt. J. Rad. Sci. Applic., Vol. 24, No. 2 (2011) 
The blood GSH decreased significantly in irradiated group, Table 2, while MDA, cholesterol and triglycerides contents significantly increased in $\gamma$-irradiated group compared control and non-irradiated groups. DP $(100 \mathrm{mg} / \mathrm{kg}$ 5 times/ week for 3 weeks) treatment post irradiation has been significantly reduced the severity of changes in comparison to irradiated rats.

TABLE 3. RBCs and platelets counts, Hb content and Het \% in different animal groups.

\begin{tabular}{|l|c|c|c|c|}
\hline \multicolumn{1}{|c|}{ Groups } & $\begin{array}{c}\text { RBCs } \\
\times 10^{6} \mu \mathrm{L}\end{array}$ & $\begin{array}{c}\text { Hb } \\
\mathrm{g} / \mathrm{dl}\end{array}$ & $\begin{array}{c}\text { Hct } \\
\%\end{array}$ & $\begin{array}{c}\text { Platelets } \\
\times 10^{3} \mu \mathrm{L}\end{array}$ \\
\hline Control & $6.49 \pm 0.0 .17^{\mathrm{b}}$ & $15.15 \pm 0.33^{\mathrm{b}}$ & $33.37 \pm 0.41^{\mathrm{b}}$ & $448 \pm 18^{\mathrm{b}}$ \\
\hline Tartaric acid & $6.56 \pm 0.20^{\mathrm{b}}$ & $15.06 \pm 0.45^{\mathrm{b}}$ & $33.94 \pm 1.1^{\mathrm{b}}$ & $480 \pm 38^{\mathrm{b}}$ \\
\hline DP $(100 \mathrm{mg} / \mathrm{kg})$ & $5.79 \pm 0.18^{\mathrm{b}}$ & $14.06 \pm 0.45^{\mathrm{b}}$ & $31.32 \pm 0.91^{\mathrm{b}}$ & $504 \pm 37^{\mathrm{b}}$ \\
\hline Irrad $(6 \mathrm{~Gy})$ & $4.61 \pm 0.33^{\mathrm{a}}$ & $11.02 \pm 0.49^{\mathrm{a}}$ & $26.68 \pm 0.82^{\mathrm{a}}$ & $343 \pm 19^{\mathrm{a}}$ \\
\hline $\begin{array}{l}\text { Irrad+ } \\
\text { Tartaric acid }\end{array}$ & $4.47 \pm 0.34^{\mathrm{a}}$ & $11.84 \pm 0.41^{\mathrm{a}}$ & $25.33 \pm 0.92^{\mathrm{a}}$ & $329 \pm 17^{\mathrm{a}}$ \\
\hline Irrad+ DP & $5.33 \pm 0.10^{\mathrm{ab}}$ & $12.29 \pm 0.34^{\mathrm{ab}}$ & $29.61 \pm 1.15^{\mathrm{ab}}$ & $442 \pm 46^{\mathrm{b}}$ \\
\hline
\end{tabular}

Legends as in Table 1 .

A significant depression of RBCs and platelet counts, Hb, Hct was observed in irradiated groups. DP treatment before $\gamma$-irradiation at 6 Gy has significantly increased the blood parameters compared to the irradiated group, Table 3.

TABLE 4. Leukocytes, neutrophils and lymphocytes counts in different animal groups.

\begin{tabular}{|l|c|c|c|}
\hline \multirow{2}{*}{ Groups } & Leukocytes & Neutrophils & \multicolumn{1}{c|}{ Lymphocytes } \\
\cline { 2 - 4 } & \multicolumn{3}{|c|}{$\times 10^{3} \mu$} \\
\hline Control & $11.62 \pm 0.68^{\mathrm{b}}$ & $4.63 \pm 0.53^{\mathrm{b}}$ & $5.93 \pm 0.75^{\mathrm{b}}$ \\
\hline Tartaric acid & $11.53 \pm 0.72^{\mathrm{b}}$ & $4.05 \pm 0.82^{\mathrm{b}}$ & $5.70 \pm 0.65^{\mathrm{b}}$ \\
\hline DP $(100 \mathrm{mg} / \mathrm{kg})$ & $12.36 \pm 0.62^{\mathrm{b}}$ & $5.6 \pm 0.79^{\mathrm{b}}$ & $6.08 \pm 0.17^{\mathrm{b}}$ \\
\hline Irrad $(6 \mathrm{~Gy})$ & $5.46 \pm 0.53^{\mathrm{a}}$ & $2.75 \pm 0.16^{\mathrm{a}}$ & $2.7 \pm 0.41^{\mathrm{a}}$ \\
\hline $\begin{array}{l}\text { Irrad+ } \\
\text { Tartaric acid }\end{array}$ & $6.22 \pm 0.46^{\mathrm{a}}$ & $2.78 \pm 0.39^{\mathrm{a}}$ & $3.28 \pm 0.17^{\mathrm{a}}$ \\
\hline Irrad+ DP & $7.26 \pm 0.66^{\mathrm{ab}}$ & $3.72 \pm 0.27^{\mathrm{b}}$ & $4.32 \pm 0.58^{\mathrm{ab}}$ \\
\hline
\end{tabular}

Legends as in Table 1.

Animals received $\gamma$-rays showed a significant decrease in blood leukocytes (total, neutrophil and lymphocyte) count, compared to control group. DP treatment to irradiated animals has significantly reduced changes in total and absolute leukocytes counts in comparison to $\gamma$-irradiated animals. Table 4. 


\section{Discussion}

The balance between oxidation and reduction reactions determines cellular redox homeostasis and plays an essential role in numerous signalling cascades including those associated with proliferation, inflammatory responses, apoptosis, and senescence. Reactive oxygen and nitrogen species (ROS; RNS) are invariable components of aerobic metabolism and are key contributors to cellular redox (Tew et al., 2011). DP lowers formation of ROS in platelets and endothelial cells, and improves cellular redox status (Chakrabarti et al., 2005), prevents membrane and mitochondrial lipid peroxidation as well as oxidative modification of low-density lipoprotein (Iuliano et al., 1996) and is an effective agent for protection of neurons from oxidative stress (Farinelli et al. 1998). DP serves as an effective scavenger in both the aqueous and lipid phases (Iuliano et al., 1995).

In the present study, serum AOPP, NO, urea and protein carbonyl levels in irradiated group were significantly increased in comparison with control. Radiation induced ROS may result in oxidative damage. Oxidative damage to proteins renders them prone to segregation and degradation. Further, carbonisation damage is un-repairable, which may impair the activity of key proteins essential for healthy survival (Nystrom et al., 2005). Radiation disrupt protein structures with consequent loss of functions, change the transport properties of lipid bilayers, the trans membrane potential of both plasma and nuclear membranes, and cause the accumulation of cytotoxic products (Ziegler and Wessels, 1998).

In treated irradiated group, DP has significantly improved the alterations that occurred in AOPP, NO, urea and protein carbonyl parameters as compared with irradiated group. DP modulation effects may be attribute to DP-antioxidant properties. The peroxyl radical scavenging activity of DP was confirmed in human erythrocytes by Kusmic et al. (2000). The antioxidant properties of DP suppress the endogenous release of vascular reactive oxygen and inflammatory species in vascular cells (Chakrabarti et al., 2005). DP scavenges oxygen radicals and protects from free radical-induced peroxidative damage in different tissues in systems which peroxidise fatty acids (Iuliano et al., 1989) and in human liver membranes (De La Cruz et al., 1992). In the present work, it is Egypt. J. Rad. Sci. Applic., Vol. 24, No. 2 (2011) 
reasonable to speculate that all these explanations together are involved in the modulatory role of DP against irradiation induced-oxidative damage in rats.

In the current study, significant inhibition of blood GSH content and significant elevation MDA, triglycerides and cholesterol levels were observed in $\gamma$-irradiated groups compared with control groups. The depletion in blood GSH level might result from diffusion through impaired cellular membranes and/ or inhibition of GSH-synthetase and glutathione reductase enzymes (Zahran et al., 2006). Lipid metabolites were elevated in serum of irradiated animals which could be attributed to acceleration of other pathways of cholesterol formation in the liver and other tissues (Pulikova and Sedlakova, 1988). Free radicals destroy the cell membranes, enhance cholesterol release and increase the lipid peroxidation (Karbowink and Reiter, 2000). The presence of polyunsaturated fatty acids in cellular membrane makes it highly susceptible for oxidative damage induced by ROS generated through radiation exposure, yielding cytotoxic break dawn lipid peroxides such as MDA (Gago-Dominguez et al., 2005).

Gamma-irradiation-induced MDA elevated levels were prevented by DP and restored the GSH levels significantly, pointing to an antioxidant effect of DP, as a phosphodiesterase inhibitor. The molecular structure of DP allows it to accept electrons, thus functioning as a free radical scavenger and antioxidant (Kim and Liao, 2008).

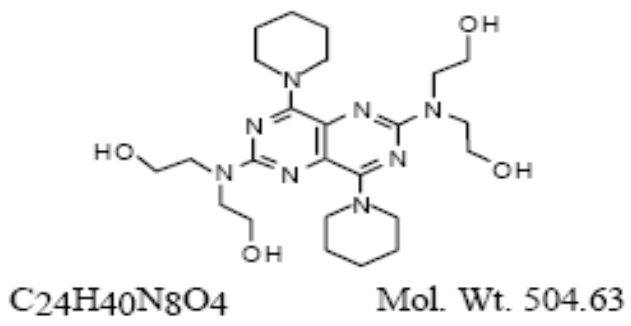

Fig. 1. Chemical structure of dipyridamole.

Serum cholesterol and triglycerides levels in $\gamma$-irradiated animals at 6Gy were increased as compared with control group, DP $(100 \mathrm{mg} / \mathrm{kg})$ treatment, ameliorated the increase in cholesterol and triglycerides levels in $\gamma$-irradiated animals. DP prevents membrane and mitochondrial lipid peroxidation as well as oxidative modification of low-density lipoprotein (Iuliano et al., 1996) and 
lower formation of ROS in platelets and endothelial cells, and improves cellular redox status. The antioxidant effect DP may be ascribed to its partition in the lipid phase of the mitochondrial membrane and not to a specific interaction with membrane proteins (Chakrabarti et al., 2005). Further, in the present study, this attenuation effect of DP may be due either to a direct inhibition of the propagation steps or a scavenger effect on the free radical species that would result from $\gamma$-irradiation.

The current results show that $\gamma$-irradiation at 6 Gy caused suppression in RBCs and platelets counts, Hct and $\mathrm{Hb}$ as well as total WBCs, lymphocyte and neutrophil counts compared to the control groups. These results are in accordance with those of Salama (2011) and Hanafi et al. (2009). Wang et al. (2006) reported that exposure of C57BL/6 mice to 6.5Gy induced a quantitative and qualitative reduction of haematopoietic stem cells (HSC), resulting from induction of senescence and impairment of HSC self-renewal via activation of the specific cellular pathways. This is complicated by thrombocytopenia and concomitant haemorrhages, besides effects in adaptive immune system resulting from apoptosis of lymphocytes and deficient lymphopoiesis (Wilkins et al., 2002). Ionizing radiation is known to induce oxidative stress through generation of ROS and RNS and resulting in imbalance of the pro-oxidant and antioxidant activities (Srinivasan et al., 2007).

DP treatment ameliorated significantly the decrease in all blood parameters in $\gamma$-irradiated animals. Hofer et al. (2002) suggested a positive role of DP and adenosine monphosphate, in supporting regeneration from severe $\gamma$-rays myelo suppression in mice. These positive effects of the tested treatment are due to increased restoration of the pools of haematopoietic progenitor cells in the bone marrow and spleen in early time intervals following termination of the treatment.

DP binds non-covalently to the most abundant protein on the RBC membrane with about a million copies per cell (van Steveninck et al., 2000). In agreement with our results, it has been reported that DP exerts an inhibitory effect on lipid peroxidation and acts as a scavenger of superoxide anion, hydroxyl radical and peroxyl radical (Iuliano et al., 1995). The radiationinduced lipid peroxidation in mouse liver and spleen was inhibited by DP pre-

Egypt. J. Rad. Sci. Applic., Vol. 24, No. 2 (2011) 
treatment 1 hour before irradiation (Udea et al., 1996). Thus DP has selective protection to RBCs against oxidative damage. DP inhibits adenosine uptake and adenosine deaminase, thus increasing its extra cellular adenosine and cyclic adenosine mono-phosphate formation. The latter modulates intracellular levels by activating adenylate cyclase activity and inhibiting phosphodiesterase activity that trigger haematopoietic stem cells to enter the cell cycle and vascular growth (Adair, 2005). DP improves micro-vascular function by increasing RBC deformability and reducing blood viscosity. In addition, it has anti-oxidant and anti-inflammatory properties that provide protection to the microvasculature (Bhavsar and Rosenson, 2010). The study could be concluded that DP may be applied to minimize radiation damage and attenuate the side effects of radiotherapy. These results observed in rats need to be confirmed in other experimental models, but could become a part of the rationale of further randomised clinical trails in patients treated by radiotherapy.

\section{References}

Adair, T. H. (2005) Growth regulation of the vascular system: an emerging role for adenosine. Am. J. Physiol. Regul. Integr. Comp. Physiol., 289, 283.

Chan, T. C., Zimm, S. L., Cleary, S. and Howell, S. B. (1988) Pharmacokinetics of intraperitoneally administered dipyridamole in cancer patients. Cancer Res., 48, 215.

Beutler, E., Duron, O. and Kelly, B. (1963) Improved method for determination of blood glutathione. J. Lab. Clin. Med., 61, 882.

Bhavsar, J. and Rosenson, R. S. (2010) Adenosine transport, erythrocyte deformability and microvascular dysfunction: an unrecognized potential role for dipyridamoletherapy. Clin. Hemorheol. Microcirc., 44, 193.

Buonanno, M., De Toledo, S. M., Pain, D. and Azzam, E. I. (2011) Long-term consequences of radiation-induced bystander effects depend on radiation quality and dose and correlate with oxidative stress. Radiat. Res., 175, 405.

Chakrabarti, S., Vitseva, O., Iyu, D., Varghese, S. and Freedman, J.E. (2005) The effect of dipyridamole on vascular cell-derived reactive oxygen species. $J$. Pharmacol. Exp. Ther., 315, 494.

Constantini, V., Talpacci, A., Bastiano, M. L., Boschetti, E., Cipolloni , S., Bisacci, R. and Nenci, G. G. (1990) Increased prostacyclin production from human veins by dipyridamole: An in-vitro and ex-vivo study. Biomed. Biochim. Acta., 49, 263. 
De La Cruz, J. P., Carrasco, T., Ortega, G., and De La Cuesta, F. (1992). Inhibition of ferrous-induced lipid peroxidation by pyrimido-pyrimidine derivatives in a combined model of permanent focal ischemia and global ischemia reperfusion. Brain Res., 597, 250.

Di Salvo, T. G., Webster, M. W., Chesebro, J. H. and Fuster, V. (1996) In: Cardiovascular drug therapy, Messerli F editor Philadelphia: W.B. Saunders, 1451.

Diener, H. C., Cunham, L., Forbes, C., Sivenius, J., Smets, P. and Lowentha, A. (1996) European stroke prevention study. 2. Dipyridamole and acetylsalicylic acid in the secondary prevention of stroke. J. Neurol. Sci., 143, 1.

Farinelli, S. E., Greene, L. A. and Friedman, W. J. (1998) Neuroprotective actions of dipyridamole on cultured CNS neurons. J. Neurosci., 15, 5112.

Fossati, P. and Prencipe, L. (1982) Serum triglycerides determined colorimetrically with an enzyme that produces hydrogen peroxide. Clin. Chem., 28, 2077.

Gago-Dominguez, M., Castelao, J. E., Pike, M. C., Sevanian, A. and Haile, R. W. (2005) Role of lipid peroxidation in the epidemiology and prevention of breast cancer. Cancer Epidemiol. Biomarkers Prev., 14, 2829.

Green, L. C., Wagner, D. A. and Gligowski, J. (1982) Analysis of nitrate, nitrite and $\{15 \mathrm{~N}\}$ mitrate im biological fluids. Anal. Biochem., 126, 131.

Hall, E. J. and Giaccia, A. J. (2006) Radiobiology for the Radiologist, $6^{\text {th }}$ ed., Lippincott Williams \& Wilkins, Philadelphia, PA.

Hanafi, N., Mansour, S. Z. and Salama, S. F., (2009) The efficacy of oral supplementation of GliSODin in reducing the oxidative stress in rats subjected to $\gamma$-radiation. Isotope Radiat. Res., 22, 23.

Hofer, M., Pospisil, M., Znojil, V., Vacek, A., Weiterova, L., Hola, J. and Vacha, J. (2002) Drugs elevating extracellular adenosine promote regeneration of haematopoietic progenitor cells in severely myelosuppressed mice: their comparison and joint effects with the granulocyte colony-stimulating factor. Eur. J. Haematol., 68, 4.

Iuliano, L., Colavita, A. R., Camastra, C., Bello, V., Quintarelli, C., Alessandroni, M., Piovella, F. and Violi, F. (1996) Protection of low density lipoprotein oxidation at chemical and cellular level by the antioxidant drug dipyridamole. Br. J. Pharmacol., 119, 1438.

Iuliano, L., Pedersen, J. Z., Rotilio, G., Ferro, D. and Violi, F. (1995) A potent chain breaking antioxidant activity of the cardiovascular drug dipyridamole. Free Radic. Biol. Med., 18, 239.

Iuliano, L., Violi, F., Ghiselli, A., Alessandroni, M. and Balsano, F. (1989) Dipyridamole inhibits lipid peroxidation and scavenges oxygen radicals. Lipids, 24, 430.

Egypt. J. Rad. Sci. Applic., Vol. 24, No. 2 (2011) 
Karbowink, M. and Reiter, R. J.(2000) Antioxidative effect of melatonin in protection against cellular damage caused by ionizing radiation. Proc. Soc. exp. Biol. Med., 225, 9.

Kim, H. and Liao, J. (2008) Translational therapeutics of dipyridamole. Arterioscler Thromb. Vasc. Biol., 28, 39.

Kusmic, C., Picano, E., Busceti, C. L., Petersen, C. and Barsacchi, R. (2000) The antioxidant drug dipyridamole spares the vitamin $\mathrm{E}$ and thiols in red blood cells after oxidative stress. Cardiovasc. Res., 47, 510.

Lowry, O., Rosenbraugh, N., Farr, L. and Rondall, R. (1951) Protein measurement with the Folin-phenol reagent. J. Biol. Chem., 193, 265.

Nystrom, T. (2005) Role of oxidative carbonylation in protein quality control and senescence. Embo. J., 24, 1311.

Petkau, A. (1987) Role of superoxide dismutase in modification of radiation injury. $B r$. J. Cancer Suppl., 8, 87.

Pospisil, M., Hofer, M., Netikova, J., Pipalova, I., Vacek, A. and Bartonickova, A. and Volenec, K. (1993) Elevation of extracellular adenosine induces radioprotective effects in mice. Radiat. Res., 134, 323.

Pulikova, E. and Sedlakova, A. (1988) Glycogenesis and lipogenesis from 14-Cglucose in vivo in rats irradiated with fractionated doses of gamma rays. Physiol. Bohemoslov., 37, 333.

Reznick, A. and Packer, L. (1994) Oxidative damage to protein: spectro photometric method for carbonyl assay. Methods Enzymol., 233, 357.

Richmound, W. (1973) Preparation and properties of the cholesterol oxidase from nacordia $s p$. and its application to the enzymatic assay of total cholesterol in serum. Clin. Chem., 19, 1350.

Salama, S. F. (2011) B-Glucan Ameliorates Gamma-Rays Induced Oxidative Injury in Male Swiss Albino Rats. Pakistan J. Zool., 43, 933.

Spitz, D. R. , Azzam, E. I. , Li, J. J. and Gius, D. (2004) Metabolic oxidation/reduction reactions and cellular responses to ionizing radiation: a unifying concept in stress response biology. Cancer Metastasis Rev., 23, 311.

Srinivasan, M., Sudheer, A., Pllai, K., Kumar, P., Sudhakaran, P. and Menon, V. (2007) Lycopene as a natural protector against gamma-radiation induced DNA damage, lipid peroxidation and antioxidant status in primary culture of isolated rat hepatocytes in vitro. Biochim. biophys. Acta., 1770, 659.

Tew, K. D., Manevich, Y., Grek, C., Xiong, Y., Uys, J. and Danyelle, M. (2011) The role of glutathione S-transferase $\mathrm{P}$ in signaling pathways and $\mathrm{S}$ glutathionylation in cancer Free Radic. Biol. Med., 51, 299.

Tobaccom, A., Meiattini, F., Moda, E. and Tarli, P. (1979) Simplified enzymic/colorimetric serum urea nitrogen determination. Clin. Chem., 25, 336. 
Ueda, T., Toyoshima, Y., Moritani, T., Ri, K., Otsuki, N., Kushihashi, T., Yasuhara, H. and Hishida, T. (1996) Protective effect of dipyridamole against lethality and lipid peroxidation in liver and spleen of the ddY mouse after whole-body irradiation. Int. J. Radiat. Biol., 69, 199.

VanSteveninck, J., Trannoy, L. L., Besselink, G. A., Dubbelman, T. M., Brand, A., deKorte, D., Verhoeven, A. J. and Lagerberg, J. W. (2000) Selective protection of RBCs against photodynamic damage by the band 3 ligand dipyridamole. Transfusion, 40, 1330.

Wang, Y., Schulte, B.A., Larue, A.C., Ogawa, M. and Zhou, D. (2006) Total body irradiation selectively induces murine hematopoietic stem cell senescence. Blood, 107, 358.

Wilkins, R. C., Wilkinson, D., Maharaj, H. P., Bellier, P. V., Cybulski, M. B. and Mclean J. R. (2002) Differential apoptotic response to ionizing radiation in subpopulations of human white blood cells. Mutat. Res., 513, 27.

Witko-Sarsat, V., Friendler, M., Nguyen-Khoa, T., Capeillere-Blandin, C., Thu Nguyen, A., Canteloup, S., Dayer Jungers, J. M., Drüeke, P. and Descamps-Latscha, B. (1998) Advanced oxidation protein products as novel mediators of inflammation and monocyte activation in chronic renal failure. J. Immuno., 161, 2524.

Yoshioka, T., Kawada, K., Shimada, T. and Mori, M. (1979) Lipid peroxidation in maternal cord blood and protective mechanism against activated oxygen toxicity in blood. Am. J. Obstet. Gynecol., 135, 372.

Zahran, A. M., Azab, K. S. and Abbady, M. I. (2006) Modulatory role of allopirinol on xanthine oxidoreductase system. Egypt. J. Rad, Sci. Applic., 19, 373.

Zar, J. H. (1999) Biostatistical analysis. Upper Saddle River, N.J.: Prentice Hall, 41.

Ziegler, C. and Wessels, J. M. (1998) Investigation of lipid peroxidation in liposomes induced by heavy ion irradiation. Radiat. Environ. Biophys., 37, 95.

(Received: 02/05/2012;

accepted: 30/05/2012)

Egypt. J. Rad. Sci. Applic., Vol. 24, No. 2 (2011) 


\title{
هل يحسن الداى بيريدامول التلف ألتأكسدي الذي تحدثه أشععة جاما في ذكور الجرذان؟ \\ صفوت فريد سلامه و نعمة محمد الفاتح \\ قسم بيولوجيا الإشعاع ، المركز القومي لبحوث وتكنولوجيا الإشعاع ، ص.

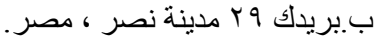

\begin{abstract}
يعـرف الــاى بيريـدامول المنبط لإنـزيم الفوسـفوداي اسـتيراز

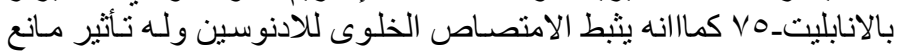

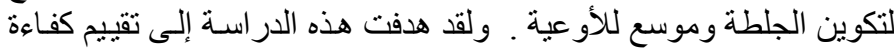

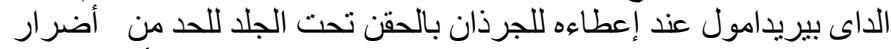

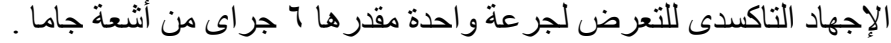

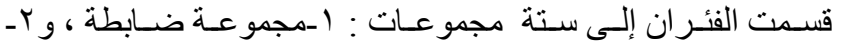

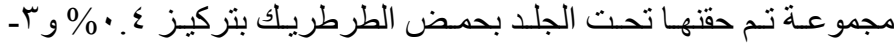

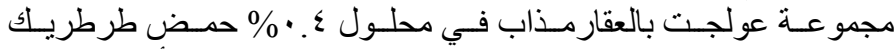

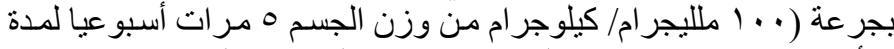

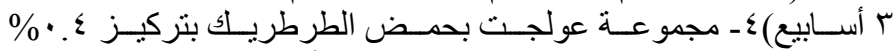

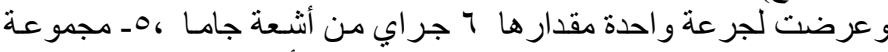

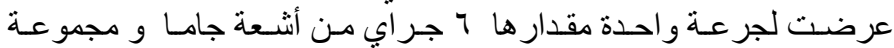

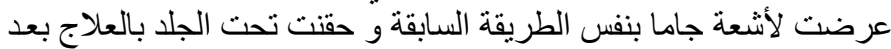

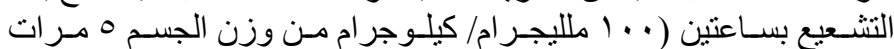
أسبو عيا لمدة ب أسابيع).

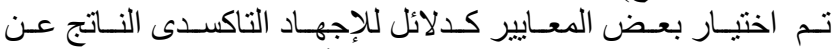

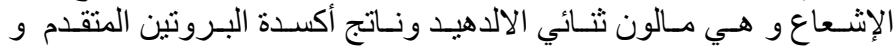

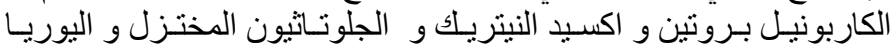

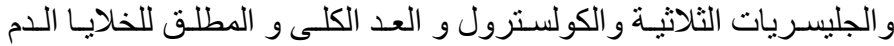

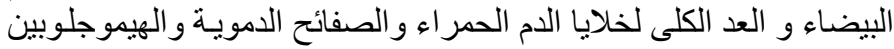

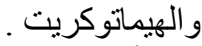

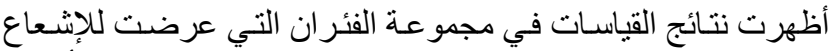

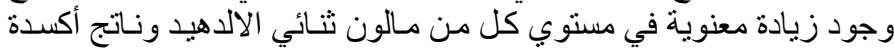

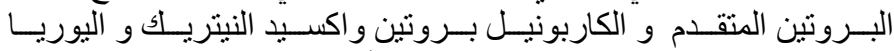

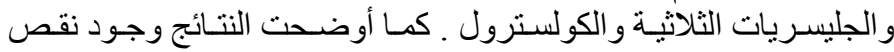

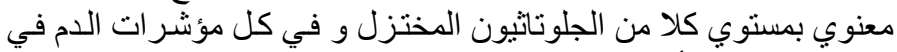

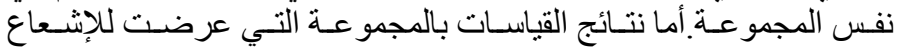

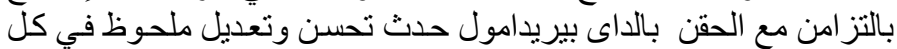

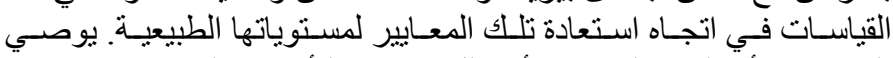

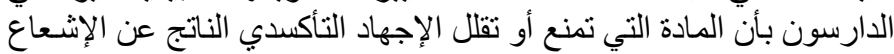

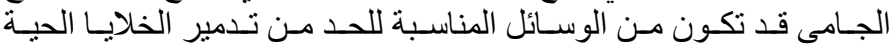

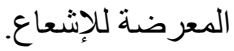

Egypt. J. Rad. Sci. Applic., Vol. 24, No. 2 (2011) 